\title{
THE PROBLEMS OF PHYSICAL AND CHEMICAL RESEARCH OF CERAMICS FROM ARCHAEOLOGICAL SITES OF THE LOWER DON
}

\author{
Sergey S. Vostrikov \\ Don State Technical University, Rostov-on-Don, Russian Federation
}

\section{Veronika V. Borodina}

Sedov Water Transport Institute - Branch of Admiral Ushakov State Maritime University, Rostov-on-Don, Russian Federation

\begin{abstract}
The present review paper analyzes the entire range of natural-science methods and techniques of archaeological ceramics research. Natural-science methods are aimed at the study of the chemical composition, various properties and features of the technology of ceramic products manufacture, which, in the case of archaeological ceramics, can solve problems that go far beyond material science, namely, to draw conclusions about the level of development, territorial and cultural relations of the person who produced this material. The whole set of natural-science methods used for the study of archaeological ceramics, is conventionally divided by us into the following main groups. The first group includes the methods for determining the age of ceramic finds, such as the method of radiocarbon dating and the method of thermoluminescent dating. The second group includes the methods for studying the physical properties of ceramics. This group includes water saturation study, petrographic method, mercury porometry, strength tests of ceramics depending on the nature of impurities, firing temperature and clay quality. The third group unites the methods for studying the microstructure of ceramic samples: optical and scanning electron microscopy, petrographic analysis. The methods for studying the sintering temperature of ancient ceramics are allocated in a separate fourth group. And the last, the fifth group unites the methods for determining the chemical and microelement composition of ceramics, of which the most promising are different options for spectral analysis, to identify the ceramic products of a particular pottery center or to identify the location of the sources of raw materials. The possibilities of each method and direction are investigated and practical recommendations for optimization of their application for solving specific problems related to the study of ceramics from the archaeological sites of the Lower Don are given.
\end{abstract}

Key words: archaeological ceramics, methods of natural sciences, chemical composition, microstructure, physical properties, technology, spectral analysis.

Citation. Vostrikov S.S., Borodina V.V., 2018. The Problems of Physical and Chemical Research of Ceramics from Archaeological Sites of the Lower Don. The Lower Volga Archaeological Bulletin, vol. 17, no. 2, pp. 70-81. (in Russian). DOI: https://doi.org/10.15688/nav.jvolsu.2018.2.6

\section{ПРОБЛЕМЫ ФИЗИКО-ХИМИЧЕСКОГО ИССЛЕДОВАНИЯ КЕРАМИКИ ИЗ АРХЕОЛОГИЧЕСКИХ ПАМЯТНИКОВ НИЖНЕГО ДОНА}

\author{
Сергей Стефанович Востриков
}

Донской государственный технический университет, г. Ростов-на-Дону, Российская Федерация

\section{Вероника Викторовна Бородина}

Институт водного транспорта им. Г.Я. Седова - филиал Государственного морского университета им. адмирала Ф.Ф. Ушакова, г. Ростов-на-Дону, Российская Федерация 
Аннотация. В этой обзорной статье проводится анализ всего спектра естественнонаучных методов и методик исследования археологической керамики. Естественнонаучные методы направлены на исследование химического состава, разнообразных свойств и особенностей технологии изготовления керамических изделий, которые в случае археологической керамики позволяют решать задачи, далеко выходящие за рамки материаловедения, а именно делать выводы об уровне развития, территориальных и культурных связях человека, этот материал производившего. Вся совокупность естественнонаучных методов, используемых для исследования археологической керамики, условно делится нами на следующие основные группы. К первой группе относятся методы определения возраста керамических находок, такие как метод радиоуглеродного датирования и метод термолюминесцентного датирования. Ко второй группе мы отнесли методы изучения физических свойств керамики, в нее входят: исследование водонасыщения, петрографический метод, ртутная порометрия, методы строительных ГОСТов, испытания керамики на прочность в зависимости от характера примесей, температуры обжига и качества глины. Третья группа - методы изучения микроструктуры керамических образцов: оптическая и сканирующая электронная микроскопия, петрографический анализ. В отдельную четвертую группу выделены методы изучения температуры спекания древней керамики. И последняя, пятая группа-методы определения химического и микроэлементного состава керамики, из которых наиболее перспективными являются разные варианты спектрального анализа, позволяющие идентифицировать керамическую продукцию конкретного гончарного центра или выявить месторасположение источников сырья. Исследуются возможности каждого метода и направления и даются практические рекомендации по оптимизации их применения для решения конкретных задач, связанных с исследованием керамики из археологических памятников Нижнего Дона.

Ключевые слова: археологическая керамика, методы естественных наук, химический состав, микроструктура, физические свойства, технология, спектральный анализ.

Цитирование. Востриков С. С., Бородина В. В., 2018. Проблемы физико-химического исследования керамики из археологических памятников Нижнего Дона // Нижневолжский археологический вестник. Т. 17, № 2. C. 70-81. DOI: https://doi.org/10.15688/nav.jvolsu.2018.2.6

Введение. Керамика является одним из древнейших материалов, созданных человеком. В археологических памятниках Нижнего Дона встречаются керамические образцы, принадлежащие к различным историческим эпохам, поэтому проблема исследования археологической керамики для нашего региона является особенно важной и актуальной. Однако при всем обилии материала исследователи при изучении керамики региона опираются в основном на типологический анализ. Не в полной мере используются возможности естественнонаучного подхода, при котором изучается химический состав, микроструктура и свойства археологической керамики, уделяется большое внимание в изучении не только формы и орнаментации керамических изделий, но и их вещественного состава. Авторами настоящей статьи поставлена цель - оценить возможности методов естественных наук для определения технологических особенностей керамики из археологических памятников Нижнего Дона и установления вероятных источников минерального сырья.

Древняя керамика глазами физика и археолога. История материалов тесно связана с историей человечества. С расширением человеческого опыта и знаний внедрялись и совершенствовались различные материалы. Новые материалы появляются только тогда, когда, с одной стороны, в них возникает острая необходимость, с другой - уровень развития технологии позволяет создать материалы необходимого качества и в достаточном количестве. С эпохи неолитической революции, с развитием производящей экономики, увеличился интерес людей к изменению природных веществ, были созданы многообразные виды материалов и продукты на их основе, в частности, изделия из глины, необожженной и обожженной, то есть керамика. Однако самые древние предметы из обожженной глины - статуэтки «палеолитических венер», самой яркой представительницей которых является так называемая Венера из Вестоницы по названию доисторического поселка на месте раскопок в Моравии, рядом с Брно на юге Чехии, возраст которой по предварительным оценкам составляет 29 тысяч лет.

Термин «керамика» обозначает изделия из обожженной глины. По-гречески «керамос» - глина. В материаловедении под керамикой понимают неорганический минеральный материал, получаемый из отформованного минерального сырья путем спекания при высоких температурах $\left(1200-2500^{\circ} \mathrm{C}\right)$. Структура 
керамики состоит из кристаллической, стекловидной (аморфной) и газовой фазы.

Глинами называется группа распространенных в природе осадочных горных пород, сложенных различными глинистыми минералами - водными алюмосиликатами - со слоистой кристаллической структурой. Важнейшими глинистыми минералами являются каолинит $\mathrm{Al}_{2} \mathrm{O}_{3} \cdot 2 \mathrm{SiO}_{2} \cdot 2 \mathrm{H}_{2} \mathrm{O}$, монтмориллонит $\mathrm{Al}_{2} \mathrm{O}_{3} \cdot 4 \mathrm{SiO}_{2} \cdot \mathrm{nH}_{2} \mathrm{O}$ и др. Глинистые минералы определяют основную особенность глин образовывать с водой пластичное тесто, способное в процессе высыхания сохранять приданную ему форму и после обжига приобретать свойства камня.

К важнейшим свойствам глин относятся пластичность, воздушная усадка и огневая усадка, огнеупорность и цвет черепка после обжига.

Пластичностью глин называется способность глиняного теста под действием внешних сил принимать заданную форму без образования трещин и устойчиво сохранять ее. Природные глины содержат различные примеси, например кварц, кальцит, слюды, соединения железа и др. Примеси понижают пластичность глин тем в большей степени, чем выше их содержание. Пластичность глин повышается с увеличением количества воды в глиняном тесте. Чем пластичнее глины, тем больше они требуют воды для получения удобного для формовки глиняного теста.

Глинистые минералы при смачивании глин водой набухают вследствие того, что поглощаемая ими вода располагается между отдельными слоями их кристаллических решеток, при этом межплоскостные расстояния решеток значительно увеличиваются. При сушке глин происходит обратный процесс, сопровождающийся усадкой.

Воздушной усадкой (линейной или объемной) называется уменьшение линейных размеров и объема образца из глиняного теста при высыхании. Воздушная усадка тем больше, чем выше пластичность глины.

При обжиге глин после удаления гигроскопической влаги и выгорания органических примесей происходит разложение глинистых минералов. Так, каолинит при температуре 500-600 ${ }^{\circ} \mathrm{C}$ теряет химически связанную воду, при этом процесс протекает с полным распа- дом кристаллической решетки и образованием аморфной смеси глинозема $\mathrm{Al}_{2} \mathrm{O}_{3}$ и кремнезема $\mathrm{SiO}_{2}$. При дальнейшем нагреве до температур 900-950 ${ }^{\circ} \mathrm{C}$ возникают новые кристаллические силикаты, например муллит $3 \mathrm{Al}_{2} \mathrm{O}_{3} \cdot 2 \mathrm{SiO}_{2}$, а также образуется некоторое количество расплава (жидкой фазы) за счет плавления наиболее легкоплавких минералов, входящих в состав обжигаемых глиняных масс [Кашкаев, Шейнман, 1978, с. 2124; Павлов, 1976, с. 25-27; Горшков, Савельев, Федоров, 1988, с. 239-241].

Пластичность глины, доступность сырья, относительная простота керамической технологии, легкость, теплостойкость, гигроскопичность, хорошие теплоизоляционные свойства керамических изделий сделали керамику одним из наиболее распространенных материалов во всем мире. Глиняную посуду широко использовали в быту на разных этапах развития общества. С другой стороны, время жизни отдельного керамического сосуда было порядка одного-трех лет, так как вследствие хрупкости они часто разбивались. Вот почему древняя керамика является одним из важнейших и наиболее распространенных исторических источников.

При этом естественные науки, такие как физика и химия, располагают богатым методологическим арсеналом по изучению керамических объектов, позволяющим вычленить большое количество ценной информации, которая может быть интересна историкам и археологам. Химический состав, технология и свойства материала находятся в тесной взаимосвязи, позволяя делать выводы об уровне развития, территориальных и культурных связях человека, этот материал производившего. Какие же естественнонаучные методы изучения керамики существуют в настоящее время и какую информацию они могут предоставить?

Определение возраста керамических находок. Археологическая наука располагает своими методами определения возраста изделий, однако появление физических методов существенно их дополнило. Данный вопрос еще в 70-х гг. прошлого века подробно рассмотрел М.С. Тайт - преподаватель физического факультета Эссексского университета, Великобритания [Тайт, 1972, с. 130-132]. Общеизвестный метод радиоуглеродного датирования в случае керамики не является наи- 
более точным, так как керамические образцы содержат углерод только в следовых количествах, в том случае, если на них имеется слой сажи в результате использования. Наиболее подходящим для керамики он считает метод термолюминесцентного датирования. Суть метода в следующем.

Если подвергнуть ионизирующему облучению какой-нибудь неорганический непроводник, то в нем образуются свободные электроны и дырки. Часть из них захватывается дефектами кристаллической решетки (вакансиями, внедренными и примесными атомами). При нагревании этого изолятора электроны и дырки освобождаются из ловушек, и если затем происходит рекомбинация электронов и дырок в центре высвечивания, то испускается свет и происходит то, что называется термолюминесценцией. Принципы метода термолюминесцентного датирования иллюстрирует рисунок 1 .

Когда обжигают «сырую» глину при температурах от 500 до $1200{ }^{\circ} \mathrm{C}$ для изготовления керамики, в термолюминесценции «высвечиваются» те дефекты кристаллического строения, которые были «набраны» глиной за предшествующие геологические эпохи. После этого ионизирующее излучение радиоактивных примесей в керамике (несколько миллионных долей урана и тория и несколько процентов калия) снова начинает «накапливать» дефекты, и «запасаемая» термолюминесценция со временем линейно нарастает от нуля. Тогда для определения возраста керамики нужно измерить: a) естественную термолюминесценцию $(L)$, «запасенную» к моменту измерения; б) чувствительность $(S)$ керамики к ионизирующему излучению, то есть возбужденный выход термолюминесценции на единицу (рад) дозы излучения ( 1 рад $=10^{-2}$ Дж поглощенной энергии излучения на 1 кг вещества); в) дозу излучения $(R)$ в радах, полученную керамикой за год. После этого возраст керамики определяется из соотношения $L / S R$.

Использование этого эффекта для датировки античной керамики показало, что, несмотря на многие присущие этому методу трудности, он обладает большими возможностями.

Изучение физических свойств керамики. Изучение физических свойств керамики является важнейшим естественнонаучным направлением в археологии. В отечественной науке изу- чением физико-механических свойств археологической керамики в разные годы занимались Н.С. Гражданкина, В.Ф. Генинг, А.В. Виноградов, Е.Г. Фильчаков, И.С. Жущиховская, Б.Л. Залищак, А.В. Гребенщиков, И.Г. Глушков и др. [Борисов, 2009 , с. 7]. Они использовали разнообразные методы исследования: водонасыщение, петрографический метод, ртутную порометрию, методы строительных ГОСТов и т. д. А.А. Бобринский [Актуальные проблемы ..., 1999, с. 33-47] использовал метод определения степени водопоглощения керамики для подсчета концентрации навоза травоядных животных, являющегося органической примесью в формовочных массах. Ряд зарубежных исследователей проводили испытания керамики на прочность в зависимости от характера примесей, температуры обжига и качества глины. Ими была установлена закономерность - с повышением температуры прокаливания прочность керамики увеличивается.

В.А. Борисов в своих работах [Борисов, 2009, с. 26-27] предложил комплексный метод определения физико-механических свойств керамики, включавший в себя измерение плотности, пористости, степени водопоглощения и твердости археологической керамики. Плотность керамики определяется по формуле: $P=m($ сух $) / V$, где $m($ сух $)-$ масса образца в сухом виде, $V$ - объем образца. Пористость и степень водопоглощения керамики измеряется при помощи водонасыщения. Формула определения пористости: $V($ пор $)=100(m($ вод $)-$ $m($ сух $)) / V$, где $m($ вод) - масса образца в насыщенном водой состоянии, степени водопоглощения $-C($ вод $)=100(m$ (вод) $-m($ сух $))$.

Твердость - это способность материала сопротивляться внедрению в него другого, более твердого тела под действием нагрузки. Она измеряется путем вдавливания в испытуемый образец твердого наконечника различной формы. В.А. Борисовым использовался метод Бринелля, который основан на вдавливании в поверхность металла стального закаленного шарика под действием определенной нагрузки. После снятия нагрузки в образце остается отпечаток. Число твердости по Бринеллю НВ определяется отношением нагрузки, действующей на шарик, к площади поверхности полученного отпечатка.

Для археологии физические свойства керамики интересны не сами по себе, а постоль- 
ку, поскольку они связаны с уровнем развития технологии. В работах В.А. Борисова [Борисов, 2009, с. 7-8] была установлена зависимость физико-механических свойств керамики от температуры прокаливания, степени обработанности глиняного сырья, характера и количества искусственных примесей. С повышением температуры обжига увеличивается твердость керамики, и снижаются ее пористость и степень водопоглощения. Плотность керамики прямо зависела от качества предварительной обработки сырья. Внесение в глину различных органических, минеральных примесей и шамота снижало твердость и плотность керамики, повышало пористость и степень водопоглощения. С учетом полученных результатов были составлены диаграммы зависимости физико-механических показателей от режима прокаливания, что позволило автору исследований в определенной степени реконструировать археологический обжиг и другие способы воздействия на глинистое сырье в процессе изготовления керамического сосуда.

Изучение структуры керамических образцов. Существуют различные методы изучения структуры материалов. С помощью макроанализа изучают структуру, видимую невооруженным глазом или при небольшом увеличении с помощью лупы. Макроанализ позволяет выявить различные особенности строения и дефекты (трещины, пористость, раковины и др.). Микроанализом называется изучение структуры с помощью оптического микроскопа при увеличении до 3000 раз. Электронный микроскоп позволяет изучать структуру при увеличении до 25000 раз. К методам, изучающим микроструктуру археологической керамики, относится оптическая и сканирующая электронная микроскопия, петрографический анализ.

Петрографический анализ обычно используется в геологии и состоит в исследовании с помощью минералогического микроскопа в плоскополяризованном свете тонких (толщиной примерно 20 мкм) срезов с камней и минералов. В археологии он первоначально использовался для исследования каменных орудий, содержащих кварц, кремни и обсидиан. Однако в настоящее время этим методом исследуют и керамические находки - микроскопическое изучение керамических образцов в прозрачном шлифе.
Подготовка шлифа для изучения его в подходящем свете заключается в изготовлении пластинки исследуемого материала толщиной порядка 0,03 мм, скрепленной канадским бальзамом между предметным и покровными стеклышками. В таком виде шлиф помещается на предметный столик поляризационного микроскопа между поляризатором и анализатором для изучения состава препарата керамики. Исследование шлифа под микроскопом позволяет определить характер обработки глиняной массы, ровность ее, степень помола, различные примеси в ней, минералогический состав глин, иногда - генетическую сторону. Пользуясь этим методом, можно в некоторой степени определить тип глин, употребляемых для изделий различного вида, особенности глин, некоторые технологические свойства, приблизительную температуру обжига изделий, характер ангоба, его толщину, отличие структуры и минералогического состава массы его от массы черепка, характер соединения ангоба с глазурью и черепком, характер глазури и другие важные детали.

Например, М.А. Кулькова и А.Н. Мазуркевич исследовали керамику из археологических памятников Двинско-Ловатьского междуречья в петрографических шлифах под микроскопом [Кулькова, Мазуркевич, 2006, с. 186187]. В шлифах был определен минеральный состав керамического теста и отощителя. Особенности минерального состава керамических фрагментов уточнялись методом инфракрасной спектроскопии. Микроструктурные характеристики и характер минеральных включений позволили предположить технологические приемы изготовления изделий. Минеральный состав теста и отощителя, способы обработки поверхности дали возможность разделить керамические фрагменты на несколько групп.

Исследование микроструктурных и текстурных особенностей проводилось и для образцов археологической керамики Томского кремля [Черная, Мананков, Дубровская, 2015, c. 108]. Минералого-петрографический анализ образцов керамики на универсальных поляризационных микроскопах подтвердил наличие в археологической коллекции Томского кремля нескольких групп керамики, отличающихся минеральным составом и текстурой, а зна- 
чит и изготовленных с помощью различных технологических приемов.

Исследование тонких керамических слоев под минералогическим микроскопом позволяет получить ценные сведения о технологии смешивания, формовки и обжига глины. К примеру, если длинные минеральные включения ориентированы параллельно стенкам сосуда, то отсюда можно заключить, что изделие, скорее всего, вращали на гончарном круге, а не формовали вручную. Аналогично, наблюдая присутствие включений некоторых минералов, можно делать определенные заключения о температуре обжига; например: если присутствует кальцит, то это говорит о том, что обжиг велся при температуре не выше $750-850{ }^{\circ} \mathrm{C}$, за которой кальцит разлагается. Однако методы изучения режимов термообработки керамики заслуживают отдельного рассмотрения.

Методы изучения температуры спекания древней керамики. Изучение термического режима производства керамики необходимо для научного обоснования уровня технологии производства древней керамики. Конечно, древние мастера подбирали температурный режим методом «проб и ошибок», наилучшие результаты фиксировались в виде передаваемых из поколения в поколение рецептов. Однако максимальные температуры, достижимые мастерами в ходе производства, могут косвенно свидетельствовать об уровне развития данной культуры.

В основе естественнонаучного направления лежат исследования изменений, происходящих с наполнителем и метаглинистой составляющей черепка при прокаливании, осуществляемые микроскопическим методом. Для реконструкции температуры археологического обжига также используется дериватографический, термогравиметрический и иные методы.

В настоящее время материаловеды точно знают, какие процессы происходят при нагреве исходного сырья в зависимости от температуры. Особенностью реакций в системах «глина - керамика» является ступенчатое протекание процесса. При этом по мере роста температуры в исходной глине могут получаться разные соединения, и процесс кристаллизации конечного продукта проходит через ряд стадий и ступеней [Черная, Мананков, Дубровская, 2015, с. 105].

Первая стадия включает две ступени. Эндоэффекты при $100-150{ }^{\circ} \mathrm{C}$ соответствуют выделению адсорбированной воды и наиболее заметному увеличению массы. Второй, более пологий и менее масштабный эндоэффект при 250-390 ${ }^{\circ} \mathrm{C}$ связан с окислением и выгоранием органики гумусовой природы.

Следующая эндотермическая реакция с четко выраженным максимумом в интервале 570-605 ${ }^{\circ} \mathrm{C}$ (в зависимости от степени кристалличности и частично от размера кристаллов) отражает потерю кристаллизационной воды и гидроксила воды, а также аморфизацию минерала при сохранении некоторой степени упорядоченности в виде структуры безводного дисиликата алюминия (метакаолинита). С помощью электронной микроскопии показано, что метафаза структурно вначале является однородной, а позже распадается и превращается в механическую смесь кремнезема, $\beta$-кварца, $\gamma$-глинозема и свободных оксидов (железа, кальция, натрия и др.). Важной реакцией здесь является полиморфный переход $\beta$-кварца в $\alpha$-кварц, который сопровождается скачкообразным увеличением объема продукта на 2,4 \%.

Экзотермические реакции начинаются с $720{ }^{\circ} \mathrm{C}$ и заканчиваются около $1300{ }^{\circ} \mathrm{C}$. Вначале метакаолинит полностью разрушается, $\gamma$-глинозем стремится к полиморфному превращению в $\alpha$-модификацию, которая позже в составе жидкой фазы участвует в формировании зародышей муллита $\left(3 \mathrm{Al}_{2} \mathrm{O}_{3} \cdot 2 \mathrm{SiO}_{2}\right)$. При температуре выше $1200{ }^{\circ} \mathrm{C}$ происходит кристаллизация избыточной аморфной кремнекислоты с образованием высокотемпературного кристобалита. Игольчатый муллит как бы армирует зерна основных фаз, в результате продукт приобретает большую плотность и прочность. За счет роста плотности происходит уменьшение его размеров (огневая усадка). По действующим сейчас нормативам кристаллическая фаза обожженного фарфорового изделия содержит до 80 \% муллита и 10-15 \% избыточного кварца.

Поэтому в работе М.П. Черной для определения термического режима детально изучался минеральный и петрографический состав керамики. На дифрактограммах всех фрагмен- 
тов посудной керамики отчетливо идентифицируются основные фазы: каолинит, кварц, новообразованные (дополнительные) полевые шпаты (альбит) и железосодержащая шпинель (герцинит), а также продукты разной степени упорядоченности метакаолинита [Черная, Мананков, Дубровская, 2015, с. 102-109].

В работе М. Тайта описывается, как можно получить достаточно точные данные о температуре обжига керамики из измерений теплового расширения. Этот метод основывается на том, что при обжиге глины происходит ее усадка в результате различных процессов спекания, например стеклования. Поэтому, когда образец керамики нагревается от комнатной температуры, он испытывает обратимое расширение, характеризующее его минералогический состав, и это расширение идет до тех пор, пока не достигается температура первоначального обжига. При дальнейшем повышении температуры начинается усадка образца, поскольку на обратимое расширение накладывается необратимое сужение, связанное с возобновлением спекания (то есть нагрев керамики следует заводить за ту температуру, при которой производился когда-то ее обжиг). Температура, при которой впервые наблюдается «чистая» усадка, и указывает на ту, при которой первоначально обжигалась керамика [Тайт, 1972, с. 139].

В работах В.А. Борисова впервые был разработан метод реконструкции режима обжига глиняной посуды на основе выведенной экспериментальным путем диаграммы зависимости твердости керамики от температуры прокаливания, а также графиков твердости стенок сосуда в поперечном разрезе [Борисов, 2009, с. 4].

Также впервые был использован метод реконструкции конкретных навыков труда древних гончаров на основе разработанных экспериментальным путем графиков зависимости физикомеханических свойств керамики от измельчения, просеивания, вымачивания и вымораживания исходного сырья, а также от внесения в формовочную массу различных органических и минеральных примесей, включая шамот.

Определение химического и микроэлементного состава керамики. Еще в работе М. Тайта в 1972 г. [Тайт, 1972, с. 135136] был сделан вывод, что при исследова- нии археологических находок наиболее подходят физические методы химического анализа, поскольку они носят экспрессный характер и практически не сопровождаются разрушением образцов. В качестве примеров он приводит оптическую эмиссионную спектроскопию, рентгеновский флуоресцентный и нейтроно-активационный анализ. В каждом случае концентрации изучаемых элементов, присутствующих в малых или следовых количествах, определяются по регистрируемому от них характеристическому электромагнитному излучению, которое испускается этими элементами при возбуждении их атомных электронов или ядер.

По результатам химического анализа археологическую керамику можно группировать, учитывая элементы, содержащиеся в ней в малых количествах. Эти элементы будут характеризовать состав глины, пошедшей на изготовление керамики. Сравнивая состав этих глин с составом местных источников глины, можно в конце концов «привязать» находки к определенным залежам глины. При сравнении химического состава керамических образцов и выходов глины важно быть уверенным в том, что перед обжигом в глину не был занесен посторонний материал. По этой причине перед химическим анализом все же следует провести минералогический анализ образцов.

Для изучения состава керамики в настоящее время используют химический анализ, разные варианты спектрального анализа (рентгеновскую флуоресценцию, атомно-абсорбционную спектроскопию), метод нейтронной активации, рентгенофазовый анализ.

К примеру, химический состав керамических фрагментов археологических памятников Двинско-Ловатьского междуречья [Кулькова, Мазуркевич, 2006, с. 186-187] определялся с помощью рентгеноспектрального флуоресцентного анализа. Полученные данные были обработаны методом математической статистики, который также позволяет разделить всю представленную выборку образцов на группы.

В работе М.П. Черной [Черная, Мананков, Дубровская, 2015, с. 104] минеральный состав керамики и глин исследовался с помощью рентгеновского дифрактометра. По результатам анализа было сделано предвари- 
тельное заключение о существовании местной сырьевой базы для развития керамического производства в средневековом Томске, что подтверждается сходством минерального состава местных глин с археологической керамикой (кроме фарфора и, видимо, изразцов).

Цель исследований золотоордынской археологической керамики [Сингатулин, 2010, c. 284-285] заключалась в идентификации подъемного керамического материала (фрагментов гончарной продукции) с помощью мультиспектральной стереофотограмметрической информационно-измерительной системы по поверхностным критериям (трасологические и мультиспектральные характеристики) и определения связи элементного состава методами вторичной ионной масс-спектрометрии и Оже-спектроскопии с местами предполагаемой добычи глины.

Метод первичной обработки предусматривал выделение «родственных» фрагментов по коэффициенту излучения керамики с помощью мультиспектральной стереофотограмметрической информационно-измерительной системы, работающей в широком спектре электромагнитного диапазона волн. Использование мультиспектральной стереофотограмметрической информационно-измерительной системы предусматривает полную автоматизацию процесса классификации керамики, дефиниции спектральных характеристик, фиксации динамики процесса рассеяния, диаграмм направленности и др. Алгоритм работы построен на основе отождествления топологических характеристик исследуемого материала с эталонным образцом. Дальнейшая процедура исследований предусматривала анализ следов инструментальной обработки с последующим анализом методом вторичной ионной масс-спектрометрии и Оже-спектроскопии.

В работе Р.Х. Храмченковой [Храмченкова, 2014, с. 176] приведены исследования химического состава неполивной керамики с раскопов Болгарского городища и глины, отобранной с современных месторождений керамического сырья вблизи средневековых поселений.

Сущность методики заключается в следующем. Навеска образца сжигается из кратера угольного электрода в дуге переменного тока до полного испарения. Спектр, получаемый на дифракционном спектрографе ДФС-458, регистрируется на фотопластинки. Определялись как основные элементы состава керамики, так и ее микроэлементный состав.

Результаты исследований выявили существенные различия по макро- и микроэлементному составу среди групп керамики. Разница макроэлементного состава определяется в значительной степени рецептурой керамического теста. Так, высокое содержание кальция соответствует добавке речной раковины, повышенное содержание кремния - добавке песка. Более интересная картина выявлена в ходе изучения так называемых рассеянных элементов (микроэлементов). Были выявлены элементы-маркеры, типичные для глин различной локализации. В исследовании проведен сравнительный анализ полученных данных для глинистого сырья и керамики. Результаты исследований показывают перспективность изучения элементного состава для определения локализации сырьевого источника керамического производства.

Проведенные исследования дали обширный материал для дальнейших работ. Как показали исследования, каждая почва и грунт имеют свой характерный набор микроэлементов, сравнимый с отпечатками пальцев у человека [Озол, 2004, с. 340-344]. Анализ керамических фрагментов показал существование таких же характерных наборов для различных групп керамики. Именно этот фактор позволяет говорить о перспективности направления изучения элементного состава археологических артефактов с целью его дальнейшей интерпретации и идентификации по отношению к сырьевым источникам.

Спектральный анализ является одним из наиболее доступных и эффективных методов. Он позволяет улавливать мельчайшие отличия в качественной характеристике проб и дает возможность выявить основные группы масс ангобов, глазурей, а иногда связать их с определенным сырьем. Однако количественное определение при обычном спектральном анализе весьма относительно, хотя в настоящее время и существует методика количественного определения спектральным анализом ряда элементов. В этих случаях полный химический анализ с использованием спектрального анализа является наиболее эффективным способом исследования, поскольку при помо- 
щи химического анализа устанавливается не только качественный состав пробы, но и количественное содержание компонентов в ней.

Разумеется, выявленный при исследованиях «родственный» химический состав на поверхности керамики может иметь и другое происхождение, например связанное с осадками, загрязнениями, многолетними наслоениями мелкодисперсного материала (пыли, частиц обломочного материала) окружения, из которого было сооружено хранилище. В этом случае достоверность результатов исследований будет определяться большим числом данных, снятых с разных участков поверхности керамики, когда картина распределения элементного состава позволит подтвердить или опровергнуть ту или иную гипотезу. Следствием таких дополнительных измерений будет усложнение и удорожание процесса обработки данных.

Вместе с тем сама возможность идентифицировать керамическую продукцию конкретного гончарного центра или выявить месторасположение источников сырья с использованием технологий мультиспектральной обработки данных является достаточно весомым аргументом в пользу организации и продолжения таких исследований.

Основные проблемы физико-химических методов исследования керамики. Почему же при таком, казалось бы, богатом и хорошо разработанном арсенале физико-химических методов их применение, в частности, для исследования археологической керамики Нижнего Дона, столь ограниченно?

Следует особо подчеркнуть, что эти анализы проводятся в рамках формально-классификационного подхода и поэтому получаемую информацию очень сложно в дальнейшем использовать для изучения историко-культурных особенностей древней керамики. Например, важно научиться определять не вообще состав сырья и формовочных масс, а именно те его особенности, которые, судя по этнографическим данным из разных районов земного шара, сами гончары считали значимыми; относительно обжига керамики необходимо выяснять не просто абсолютную температуру, но и длительность выдержки изделия при конечной температуре нагрева, а также учитывать, что температура в разных частях устройства для обжига могла различаться иногда на несколько сотен градусов.

Почему же информацию, получаемую по керамике учеными-естественниками, пока трудно успешно использовать для расширения наших знаний об истории гончарства и древнего населения? Причин, с нашей точки зрения, три. Первая состоит в том, что существующие инструментальные методы анализа разрабатывались в сфере материаловедения и промышленной керамической технологии, то есть в областях знания, очень далеких от археологии. Вторая причина, тесно связанная с первой, - археологи часто затрудняются поставить перед учеными-естественниками корректную исследовательскую задачу. Это происходит, с одной стороны, из-за того, что большинство из них недостаточно знакомы с возможностями естественнонаучных методов, а с другой - из-за отмеченной выше специфики формально-классификационного подхода к объекту изучения. Третья причина состоит в совершенно недостаточной разработанности методических правил перевода физико-технических характеристик керамики на язык исторических понятий. Последнее позволило бы значительно повысить результативность естественнонаучных методов исследования археологической керамики.

Решение всех этих проблем невозможно без тесного сотрудничества специалистов в области физики, материаловедения и археологии.

Заключение. Тщательное исследование керамики различных археологических объектов с применением химического, спектрального, микроскопического, рентгеновского анализов имеет большие преимущества перед обычным ее изучением, позволяет более обстоятельно обработать материал, исследовать технологические процессы, связанные с изготовлением тех или иных изделий, определить некоторые приемы, уровень и технологические возможности средневековых мастеров. Только используя данные таких анализов, мы можем полнее осветить вопросы исторического развития керамического ремесла, более определенно и конкретно говорить о характере его для каждого периода, о специфике и общих чертах производства различных районов, изучать экономику ремесла. 


\section{ИЛЛЮСТРАЦИИ}

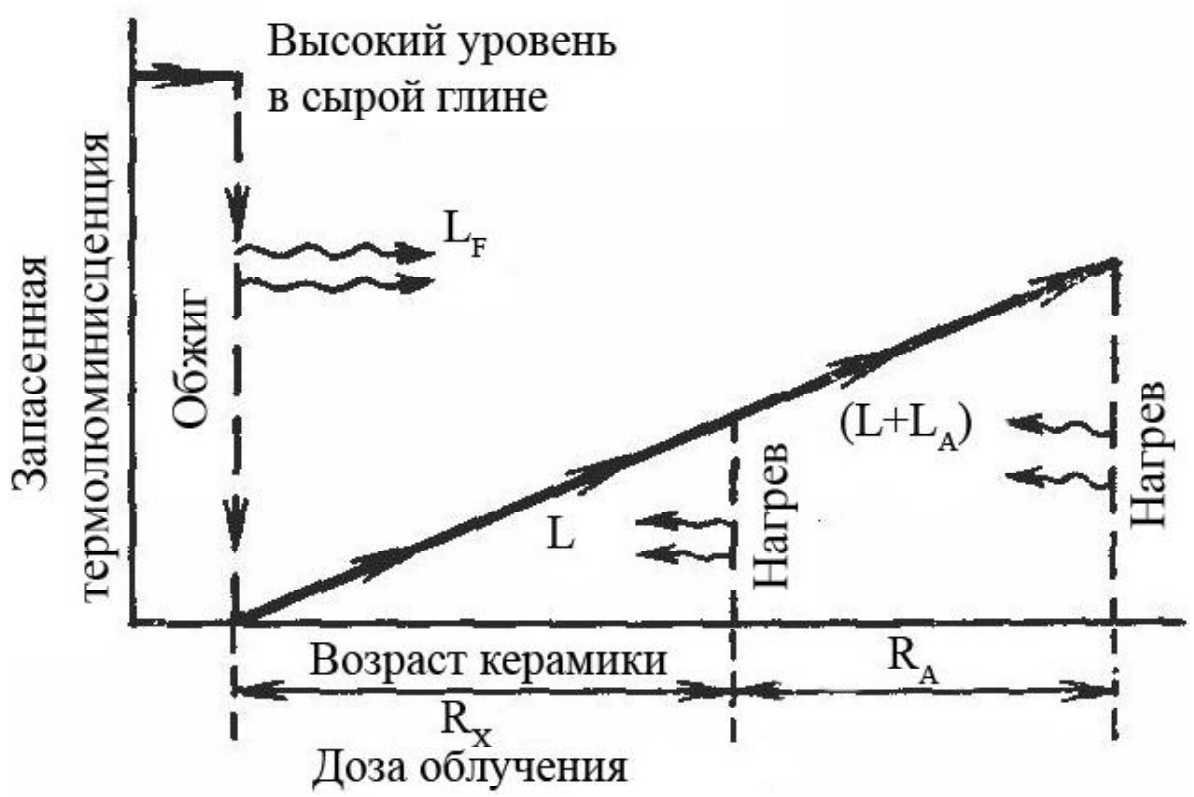

Рис. 1. Термолюминесцентная «история» образца глины:

$L_{f}$ - термолюминесценция, испущенная при обжиге сырой глины; $L$ - естественная термолюминесценция, приобретенная после обжига в результате облучения ( $R$ рад/год) от радиоактивных примесей в керамике;

$L_{a}$ - дополнительная термолюминесценция, испущенная после облучения известной дозой $\left(R_{a}\right.$ рад)

от калиброванного источника. Чувствительность $S$ керамики к ионизирующему излучению определяется как отношение $L_{a} / R_{a}$

Fig. 1. Thermoluminescent "history" of the clay sample:

$L_{f}$ - thermoluminescence emitted during the firing of raw clay; $L$ - natural thermoluminescence acquired after firing as a result of irradiation ( $R \mathrm{rad} /$ year) from radioactive impurities in ceramics; $L_{a}$ - additional thermoluminescence emitted after irradiation with a known dose $\left(R_{a}\right.$ rad $)$ from a calibrated source. The sensitivity $(S)$ of ceramics to ionizing radiation is defined as the ratio $L_{a} / R_{a}$ 


\section{СПИСОК ЛИТЕРАТУРЫ}

Актуальные проблемы изучения древнего гончарства : (коллектив. моногр.) / под ред. А. А. Бобринского, 1999. Самара : Изд-во СамГПУ. 233 с.

Борисов В. А., 2009. Опыт разработки и применения экспериментальных методов исследования керамики (по материалам эпохи бронзы Верхнего Приобья) : автореф. дис. ... канд. ист. наук. Барнаул. 28 с.

Горшков В. С., Савельев В. Г., Федоров Н. Ф., 1988. Физическая химия силикатов и других тугоплавких соединений. М. : Высшая школа. $400 \mathrm{c}$.

Кашкаев И. С., Шейнман Е. Ш., 1978. Производство глиняного кирпича. М. : Высшая школа. 248 c.

Кулькова М. А., Мазуркевич А. Н., 2006. Минералогические и химические характеристики керамики из археологических памятников Двинско-Ловатьского междуречья // Федоровская сессия : тез. докл. Междунар. науч. конф. СПб. С.186-188. RMS DPI: http:// www.minsoc.ru/2006-1-67-0

Озол А. А., 2004. Процессы полигенного нефтегазо- и рудообразования и их экологические последствия. Казань : Плутон. 448 с.

Павлов В. Ф., 1976. Физико-химические основы обжига изделий строительной керамики. М. : Стройиздат. $240 \mathrm{c}$.

Сингатулин Р. А., 2010. О некоторых возможностях стереофотограмметрических технологий при исследовании массового керамического материала // Известия Самарского научного центра Российской академии наук. Т. 12, № 6. C. 284-286.

Тайт М., 1972. Влияние естественных наук на археологию // Успехи физических наук. Т. 107, вып. 1 (май). С. 125-140.

Храмченкова Р. Х., 2014. Химический состав глин как индикатор сырьевого источника // Поволжская археология. № 2 (8). С. 176-204.

Черная М. П., Мананков А. В., Дубровская В.С., 2015. Опыт использования методов естественных наук для изучения археологической керамики Томского кремля // Вестник Томского государственного университета. История. №3 (35). C. 102-110.

\section{REFERENCES}

BobrinskiyA.A. (ed.), 1999. Modern Problems of Studying Ancient Pottery (Collective Monograph). Samara, Izd-vo SamGPU. 233 p. (in Russian).

Borisov V.A., 2009. Experience in the Development and Application of Experimental Methods for the Study of Ceramics (Based on the Upper $\mathrm{Ob}$ Materials of the Bronze Age). Cand. hist. sci. abs. diss. Barnaul. 28 p. (in Russian).

Gorshkov V.S., Savelyev V.G., Fedorov N.F., 1988. Physical Chemistry of Silicates and Other Refractory Compounds. Moscow, Vysshaya shkola Publ. 400 p. (in Russian).

Kashkaev I.S., Scheinman E.S., 1978. Production of Clay Bricks. Moscow, Vysshaya shkola Publ. 248 p. (in Russian).

Kulkova M.A., Mazurkevich A.N., 2006. Mineralogical and Chemical Characteristics of Ceramics from Archaeological Monuments of the DvinaLovatsky Interfluve. Fedorovskaya sessiya. Tezisy dokladov mezhdunarodnoy nauchnoy konferentsii. Saint Petersburg, pp. 186-188. RMS DPI: http://www.minsoc.ru/2006-1-67-0. (in Russian).

Ozol A.A., 2004. Processes of Polygenic Oil, Gas and Ore Formation and the Ecological Consequences. Kazan, Pluton Publ. 448 p. (in Russian).

Pavlov V.F., 1976. Physico-Chemical Principles of Firing Building Ceramic Products. Moscow, Stroyizdat Publ. 240 p. (in Russian).

Singatulin R.A., 2010. On Some Possibilities of Stereophotogrammetry Technologies in the Research ofCeramic Material. Izvestiya Samarskogo nauchnogo tsentra Rossiyskoy akademii nauk, vol. 12, no. 6, pp. 284-286. (in Russian).

Tite M.S, 1972. The Impact of the Natural Sciences on Archaeology. Uspekhi fizicheskikh nauk, vol. 107, iss. 1 (May), pp. 125-140. (in Russian).

Khramchenkova R.Kh., 2014. Chemical Composition of the Clays as an Indicator of Raw Material Sources. The Volga River Region Archaeology, no. 2 (8), pp. 176-204. (in Russian).

Chernaya M.P., Manankov A.V., Dubrovskaya, V.S., 2015. Experience of Using the Methods of Natural Sciences in the Study of Archaeological Ceramics of Tomsk. Tomsk State University Journal of History, no. 3 (35), pp. 102-110. (in Russian). 


\section{Information about the Authors}

Sergey S. Vostrikov, Candidate of Sciences (History), Associate Professor, Department of Archaeology and History of Culture, Don State Technical University, Gagarina Sq., 1, 344000 Rostovon-Don, Russian Federation, sekoh@yandex.ru.

Veronika V. Borodina, Candidate of Sciences (Physics and Mathematics), Associate Professor of Department of Mathematics, Natural Sciences and General Professional Disciplines, Sedov Water Transport Institute - Branch of Admiral Ushakov State Maritime University, Sedova St., 8, 344006 Rostov-on-Don, Russian Federation, nika.nicka-borodina@yandex.ru.

\section{Информация об авторах}

Сергей Стефанович Востриков, кандидат исторических наук, доцент кафедры археологии и истории культуры, Донской государственный технический университет (ДГТУ), пл. Гагарина, 1, 344000 г. Ростов-на-Дону, Российская Федерация, sekoh@yandex.ru.

Вероника Викторовна Бородина, кандидат физико-математических наук, доцент кафедры математики, естественнонаучных и общепрофессиональных дисциплин, Институт водного транспорта им. Г.Я. Седова - филиал Государственного морского университета им. адмирала Ф.Ф. Ушакова, ул. Седова, 8, 344006 г. Ростов-на-Дону, Российская Федерация, nika.nicka-borodina@yandex.ru. 